\title{
Spatial-temporal variation of Paralonchurus brasiliensis (Actinopterygii: Sciaenidae) density in relation to some environmental factors on the inner shelf of south-eastern Brazilian coast
}

\author{
EUDRIANO FLORÊNCIO DOS SANTOS COSTA ${ }^{1}$, GUSTAVO MONTEIRO TEIXEIRA ${ }^{2}$, FÚLVIO AURÉLIO \\ DE MORAIS FREIRE ${ }^{3}$ AND ADILSON FRANSOZO ${ }^{2}$ \\ ${ }^{1}$ Postgraduate Programme in Biological Oceanography, Institute of Oceanography, Universidade de São Paulo, Praça do \\ Oceanográfico 191, SP, Brazil, Zip code: 05508-120, ${ }^{2}$ Postgraduate Programme in Zoology, Institute of Bioscience, Universidade \\ Estadual Paulista, Botucatu, SP, Brazil, Zip code: 59625-900, ${ }^{3}$ Postgraduate Programme in Ecology, Centre of Bioscience, \\ Universidade Federal do Rio Grande do Norte, Praia de Mãe Luiza, s/n, Natal, RN, Brazil, Zip code: 59014-100
}

\begin{abstract}
The temporal and spatial variation of Paralonchurus brasiliensis density (fish per $\mathrm{m}^{2}$ ) in relation to environmental factors was studied on the coasts of Ubatuba and Caraguatatuba, south-eastern Brazil. The fish were collected by shrimp fishery trawl on a monthly basis from January to December, 2002. Seven depths were previously established and for each one the temperature, salinity, organic matter content and grain size of the sediment $(\varphi)$ was measured. The seasonal analysis of temperature and salinity indicated the presence of the water masses South Atlantic Central Water (SACW) and Coastal Waters (CW) acting in the study area. A total of 29,808 fish were collected during the study period. The highest densities were registered during the summer and autumn indicating an association with CW. The fish population moved to shallow depths during the intrusion of the cold water mass, SACW. The highest densities were registered in depths where the sediment composition ranged from fine sand to silt-clay. Thus, the temperature and type of the sediment are the main environmental factors which affect the spatial-temporal variation of $\mathrm{P}$. brasiliensis density in south-eastern Brazil.
\end{abstract}

Keywords: banded croaker, density variation, environmental factors, south-eastern Brazil

Submitted 18 August 2010; accepted 18 August 2011; first published online 11 November 2011

\section{INTRDDUCTION}

Sciaenid fish are reported to be the most important fishery resource in the coastal and estuarine ecosystems of the world (Chao, 1986; Nelson, 2006). It is also the most abundant family of the soft-bottom demersal fish community on the coasts of southern and south-eastern Brazil (Rocha \& Rossi-Wongtschowski, 1998). Among them, the species considered for this study was the banded croaker, Paralonchurus brasiliensis (Steindachner, 1996), a sciaenid that is very frequent, abundant and a common by-catch of shrimp fishery trawls on the south-eastern Brazil coast (Nonato et al., 1983; Braga et al., 1985; Braga, 1990; Haimovici et al., 1996). This species is widely distributed along the Atlantic coast from Central to South America and it can reach $30 \mathrm{~cm}$ in total length (Menezes \& Figueiredo, 1980). Banded croaker is considered a keystone species associated with shallow waters (Rossi-Wongtschowski et al., 2008),

Corresponding author:

E.F. Costa

Email: eudriano@usp.br playing an important role in the trophic structure of the ecosystem (Soares \& Vazzoler, 2001; Soares et al., 2008).

The depth, substrate type, temperature and salinity have been reported as the main environmental factors that affect the demersal fish populations (Koranteng, 2001; Araújo et al., 2002; Catalán et al., 2006; Katsanevakis et al., 2009). Seasonal fluctuations in the by-catch capture are associated with the oceanographic factors, such as, the intrusion and return flow of the water masses that implies changes of the temperature, salinity and nourishment conditions (Dias \& Katsuragawa, 2009). According to Pires-Vanin et al. (1993) the movements of the water masses also influence the seasonal distribution of the benthic organisms and dynamics of the ecosystems.

Identifying changes in the abundance of demersal fish in space and time, as well as to investigate correlates with environmental factors are important for fishery management and the marine ecosystems. Moreover, changes in the abundance of keystone species have critical effects on community structure and ecosystem function (Jennings et al., 2000). Thus, the aim of the present work was to contribute to the knowledge on the temporal and spatial variation in the density of $P$. brasiliensis on the south-eastern Brazil coast, explaining these variations through characterization of the 
environmental data, such as temperature, salinity and sediment characteristics.

\section{MATERIALS AND METHDDS}

\section{Study area}

The study sites are located on the inner platform of the coastal system of Ubatuba and Caraguatatuba, northern coast of São Paulo State, south-eastern Brazil. The Caraguatatuba region is considered a sheltered area as compared to Ubatuba due to the presence of the islands of Vitória, Búzios and São Sebastião (Figure 1). These areas are strongly influenced by three water masses: Tropical Waters (TW) with high temperature and salinity (TW, $\mathrm{T}>20^{\circ} \mathrm{C}$ and $\mathrm{S}>36$ ); South Atlantic Central Waters (SACW) with low temperature and salinity (SACW, $\mathrm{T}<20^{\circ} \mathrm{C}, \mathrm{S}<36$ ) and Coastal Waters (CW) with high temperature and low salinity $\left(\mathrm{CW}, \mathrm{T}>20^{\circ} \mathrm{C}, \mathrm{S}<36\right)$ (Castro-Filho et al., 1987; Castro-Filho \& Miranda, 1998). The main factor that influences the environmental conditions in the study areas is the seasonal presence of the SACW on the inner shelf in isobaths from 10 to $50 \mathrm{~m}$ (Pires-Vanin \& Matsuura, 1993). Especially during summer and later spring, a thermocline is formed in the depths ranging from 20 to $50 \mathrm{~m}$ with the upper layer filled with $\mathrm{CW}$ and the lower layer with SACW (Matsuura, 1986). During winter the SACW is restricted to the outer shelf and the inner shelf is filled with the CW (Castro-Filho et al., 1987).

\section{Data collection}

The specimens of $P$. brasiliensis were captured from January to December 2002. The seasons of the years were defined as summer (January to March), autumn (April to June), winter (July to September) and spring (October to December). The samplings were carried out using a shrimp-fishing boat equipped with two otter trawl nets. A total of seven mean depths $(5,10,15,20,25,30$ and $35 \mathrm{~m})$ based on the fish distribution were established for trawling (Figure 1). Each depth was trawled over 30 minutes sampling an area of $18,000 \mathrm{~m}^{2}$ according Castilho et al. (2008a). After trawling, the specimens of $P$. brasiliensis were separated from the other organisms captured and the number of individuals collected was registered.

The environmental factors, such as, temperature, salinity, organic matter and the mean grain size of the sediment $(\mathrm{phi}=\varphi)$ were calculated in each depth. Water samples were taken with a Nansen bottle. Temperature measurements and water samples for salinity analysis were taken at discrete depths also with a Nansen bottle. An echobathymeter coupled with a Global Positioning System was used to determine the mean depth. Sediment samples were collected in each depth with a Van Veen grab $\left(0.06 \mathrm{~m}^{2}\right)$. In the laboratory about $200 \mathrm{~g}$ of the sediment was dried at $70^{\circ} \mathrm{C}$ for 24 hours, divided into subsamples and submitted to organic matter and grain-size analysis (Mantelatto \& Fransozo, 1999). The organic matter (\%) content was obtained following Mantelatto \& Fransozo (1999) and the grain-size composition following Castilho et al. (2008a, b).

The sediment size was calculated in accordance with the Wentworth (1922) scale, in which the sediment is sieved in six sieves with different diameters, as follows: sediment sieved through $2 \mathrm{~mm}=$ gravel; $2.0 \dashv 1.0 \mathrm{~mm}=$ very coarse sand; $1.0 \dashv 0.5 \mathrm{~mm}=$ coarse sand; $0.5 \dashv 0.25 \mathrm{~mm}=$ medium sand; $\quad 0.25 \dashv 0.125 \mathrm{~mm}=$ fine sand; $0.125 \dashv 0.063 \mathrm{~mm}=$ very fine sand, and smaller particles were classified as siltclay. Cumulative particle-size curves were plotted using the $\varphi$ scale with values corresponding to the 16th, 50th and

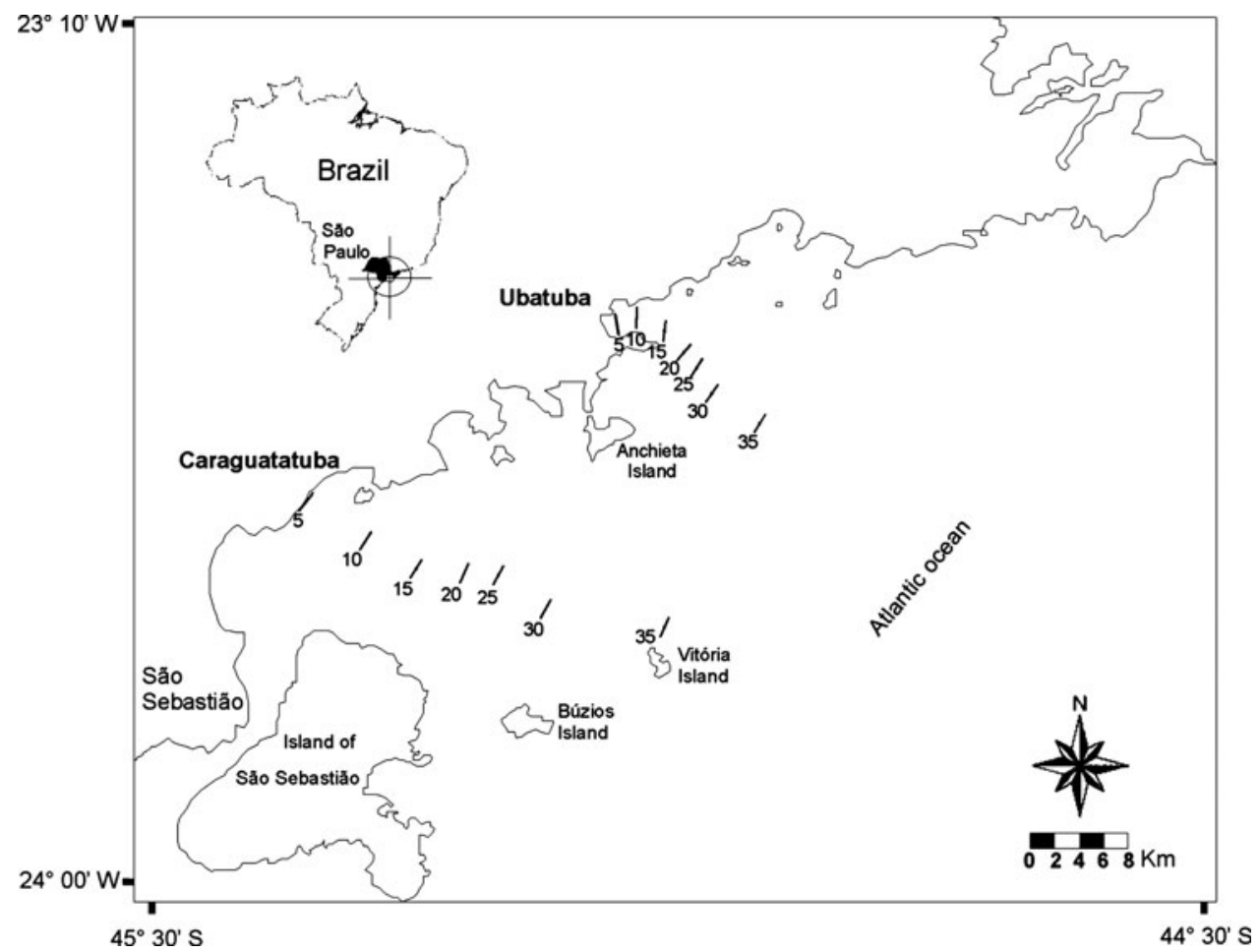

Fig. 1. Map of study area: Ubatuba and Caraguatatuba indicating the sampling mean depths $(5,10,15,20,25,30$ and $35 \mathrm{~m})$. 
84th percentiles being used to determine the mean diameter (Md) of the sediment, as per the equation: $M d=\left(\varphi_{16}+\right.$ $\left.\varphi_{50}+\varphi_{84}\right) / 3$ (Folk \& Ward, 1957). The $\varphi$ values were calculated using the equation proposed by Tucker (1988), where $\varphi=-\log _{2} \mathrm{~d}$ (d, grain diameter in $\mathrm{mm}$ ). Finally, the type of sediment of each mean depth was classified based on $\varphi$ value ranges: $-1=\varphi<0$ (very coarse sand); $0=\varphi<1$ (coarse sand); $1=\varphi<2$ (medium sand); $2=\varphi<3$ (fine sand); $3=\varphi<4$ (very fine sand) and $\varphi \geq 4$ (silt-clay).

\section{Data analysis}

The spatial and temporal variation of the temperature and salinity were explored through the construction of isothermal and isohaline diagrams generated by surfer Software (Golden Software, 2002). The interpolation was made by a 'kriging algorithm' for a linear variogram model. In this method, the contouring creates different size polygons from the dataset, and for this reason, the generated diagrams may not match exactly the sampled area.

The density of $P$. brasiliensis was calculated as: total number of fish collected divided by area trawled $\left(\mathrm{m}^{2}\right)$ multiplied by 1000 .

Two-way analysis of variance was applied to test the spatial-temporal interaction of the environmental variables (temperature, salinity, organic matter and $\varphi$ value) and density (fish per $\mathrm{m}^{2}$ ), considering the region, season and depths as factors (Gotelli \& Ellison, 2004). The influence of the environmental factors on the species density was evaluated by multiple linear regressions. The multiple correlation coefficient $(R)$ was used to measure the density variability explained by the independent environmental factors (Cohen et al., 2003). The Student's $t$-test was applied to test the significance of each environmental variable to the multiple regression models. Only significant variables were included in the final model. Prior to the analysis, the data were tested for normality and homogeneity of variances using the Kolmogov-Smirnov and Levene's tests. The data were $\log _{10}(\mathrm{x}+1)$ transformed where appropriate (Zar, 1999). The mean \pm standard deviation is given in parentheses in the text.

\section{RESULTS}

The statistical analysis showed significant variation of the temperature and salinity by season and depth, however only spatial variation was observed for organic matter and $\varphi$ in the study regions (Table 1). In general, water temperature and salinity ranged from 16 to $29.5^{\circ} \mathrm{C}(22.3 \pm 2.50)$ and 33 to $37^{\circ} \mathrm{C}(35.4 \pm 1.01)$, respectively. The highest values of temperature were registered in depth up to $20 \mathrm{~m}$ isobath at Ubatuba and $15 \mathrm{~m}$ isobath at Caraguatatuba along with low values of salinity. However, the lowest temperature and highest salinity occurred in depths that ranged from 20 to $35 \mathrm{~m}$. The seasonal and spatial variations of temperature and salinity for Ubatuba and Caraguatatuba are shown in Figures 2 \& 3, respectively.

The organic matter content ranged from 0.8 to $17.4 \%$ $(3.87 \pm 3.09)$ showing highest values in the depths up to $10 \mathrm{~m}$ at Ubatuba and 15 and $20 \mathrm{~m}$ at Caraguatatuba. The minimum value of $\varphi$ registered was 0.24 and maximum was $6.42(3.63 \pm 1.44)$ in both regions. In Ubatuba region a decrease of the $\varphi$ towards the mean depth of $35 \mathrm{~m}$ was observed indicating an increase in the mean size of the sediment grain, whereas at Caraguatatuba the highest $\varphi$ value was registered in depths of 15 and $20 \mathrm{~m}$ indicating a predominance of silt-clay. The $\varphi$ analyses indicated that the sediment composition in both regions ranged from coarse sand to silt clay. The seasonal and spatial variations of organic matter and $\varphi$ are shown for both regions in Figure 4 .

A total of 29,808 specimens of $P$. brasiliensis were collected from the shrimp fishery trawl during the study period. Out of this, 12,642 individuals were collected at Ubatuba and 17,166 at Caraguatatuba. The density in the former region ranged from 0.13 to 108.9 fish $\mathrm{m}^{-2}(13.39 \pm 17.93)$ whereas in the latter, it ranged from 0.12 to 134.69 fish $\mathrm{m}^{-2}$ (18.18 \pm 22.57). No significant difference was found between the densities of $P$. brasiliensis collected from the two regions. On the other hand the density varied significantly by season and depth (Table 2). Thus, the highest densities were registered during the summer and autumn and the lowest during the winter and spring. In general, the highest density was registered in the depth-range of $15-25 \mathrm{~m}$. No individual was captured in $35 \mathrm{~m}$ isobaths during the winter and 30 and $35 \mathrm{~m}$ isobaths during the spring (Figure 5).

In general, the highest densities of $P$. brasiliensis were registered in temperatures that ranged from 22 to $24^{\circ} \mathrm{C}$ and salinities that ranged from 34 to 36 at Ubatuba and 36 to 38 at Caraguatatuba. In relation to characteristics of the sediment, the highest density was registered in sediment in which the organic matter content ranged from 2 to $4 \%$ and $\varphi$ ranged from 2 to 5 at Ubatuba and 5 to 6 at Caraguatatuba (Figure 6).

The results of the application of the multiple regression were significant for Ubatuba $(F=6.64 ; P<0.001)$ and Caraguatatuba $(F=5.59 ; P<0.001)$ with the environmental variables affecting positively the variance of $P$. brasiliensis

Table 1. Results of the two-way analysis of variance of mean environmental variables by region, season and transect. Significant differences at the level of $0.05^{*}$ and $0.01^{* *}$.

\begin{tabular}{|c|c|c|c|c|c|c|c|c|}
\hline \multirow[t]{3}{*}{ Effect } & \multicolumn{8}{|c|}{ Environmental variables } \\
\hline & \multicolumn{2}{|c|}{ Temperature } & \multicolumn{2}{|c|}{ Salinity } & \multicolumn{2}{|c|}{ Organic matter } & \multicolumn{2}{|l|}{$\varphi$} \\
\hline & $\mathbf{F}$ & $P$ & $\mathbf{F}$ & $P$ & $\mathbf{F}$ & $P$ & $\mathbf{F}$ & $P$ \\
\hline Region & 2.27 & 0.134 & 8.99 & $0.003^{* *}$ & 1.711 & 0.193 & 0.593 & 0.443 \\
\hline Season & 13.63 & $0.000^{* *}$ & 2.777 & $0.004^{*}$ & 2.519 & 0.06 & 0.337 & 0.799 \\
\hline Region $\times$ season & 10.68 & $0.000^{* *}$ & 5.98 & $0.001^{* *}$ & 1.122 & 0.342 & 0.254 & 0.859 \\
\hline Depth & 9.639 & $0.000^{* *}$ & 3.247 & $0.005^{* *}$ & 11.62 & $0.000^{* *}$ & 32.33 & $0.000^{* *}$ \\
\hline Region $\times$ depth & 0.145 & 0.99 & 0.41 & 0.871 & 51.1 & $0.000^{* *}$ & 5.94 & $0.000^{* *}$ \\
\hline
\end{tabular}




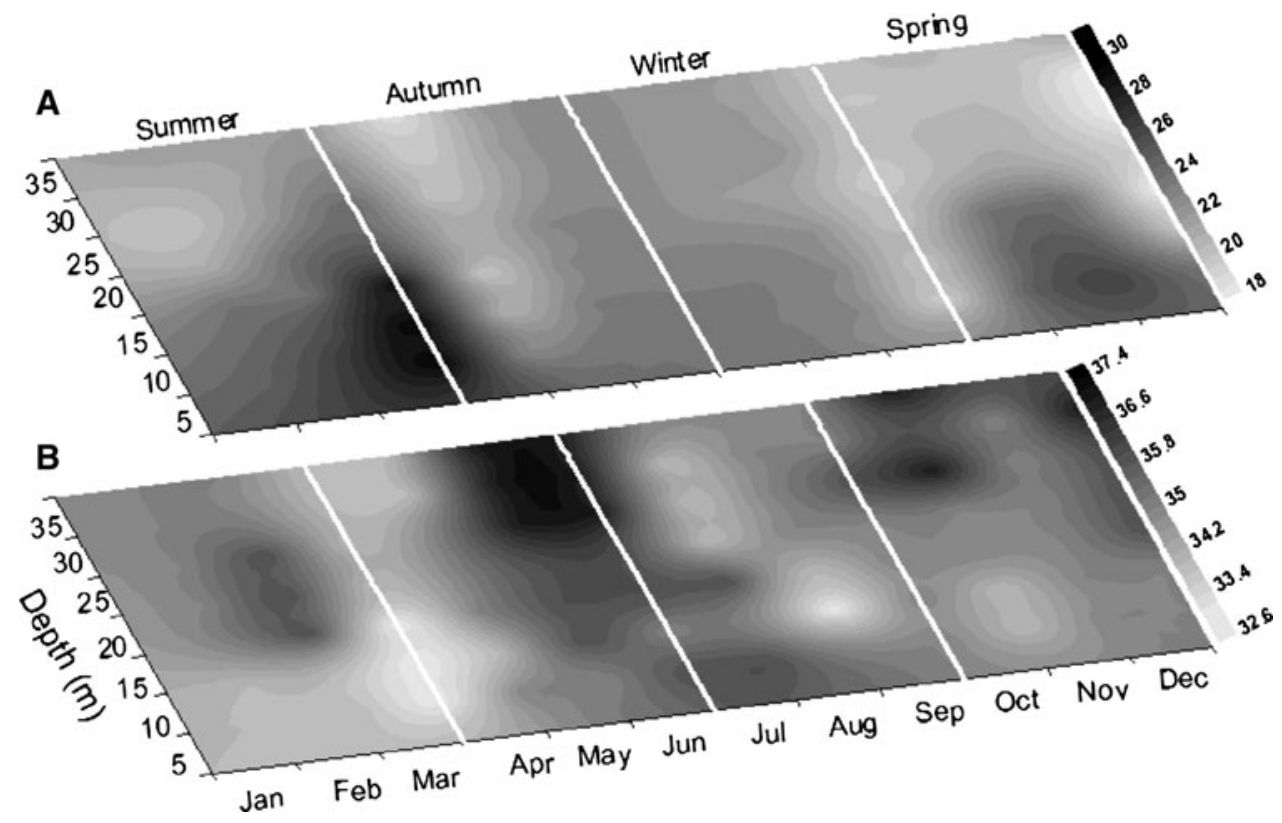

Fig. 2. Spatial and temporal variation of isotherms (A) and isohalines (B) at Ubatuba region, south-eastern Brazilian coast. Isotherms and isohaline are separated by $0.5^{\circ} \mathrm{C}$ and 0.2 , respectively.

density. In the first region, the temperature $(t=2.90, P<0.01)$ and $\varphi(t=2.42, P<0.05)$ explained $50.17 \%$ of the variance, however no significant effect of the salinity $(t=0.20, P>$ $0.05)$ and organic matter $(t=0.11, P>0.05)$ was observed In relation to the former region, the organic matter $(t=1.99$, $P<0.05)$ and the $\varphi(t=3.13, P<0.01)$ were the most important factors explaining $48.92 \%$ of the variance. On the other hand, no significant effect of the temperature $(t=1.57 ; P>$ $0.05)$ and salinity $(t=-0.27 ; P>0.05)$ was observed in Caraguatatuba. The final model for both regions was expressed as follows: $\mathrm{D}_{\text {Ubatuba }}=-2.50+0.11^{*} \mathrm{~T}+0.23^{*} \varphi$ and $\mathrm{D}_{\text {Caraguatatuba }}=-1.05+0.82^{*} \mathrm{OM}+1.37^{*} \varphi$ where: $\mathrm{D}=$ density $\left(\right.$ fish $\left./ \mathrm{m}^{2}\right), \quad \mathrm{T}=$ temperature, $\varphi=$ phi and $\mathrm{OM}=$ organic matter.

\section{DISCUSSION}

This investigation registers a significant variation in the environmental factors and density of $P$. brasiliensis during the study period in south-eastern Brazil. The fish capture fluctuates in space and time (Jennings et al., 2000). Lowe-Mcconnell $(1977,1987)$ reported that the depth, water

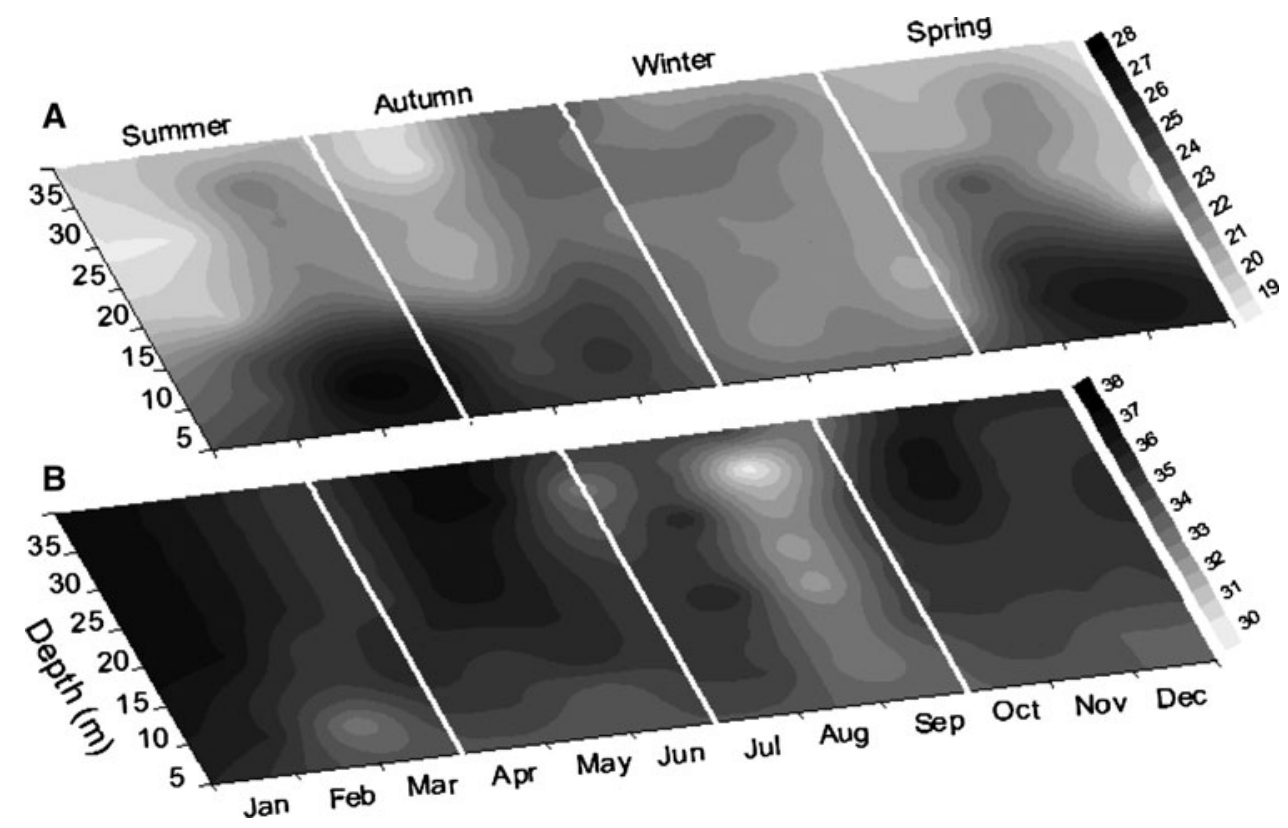

Fig. 3. Spatial and temporal variation of isotherms (A) and isohalines (B) at Caraguatatuba region, south-eastern Brazilian coast. Isotherms and isohaline are separated by $0.5^{\circ} \mathrm{C}$ and 0.5 , respectively. 




Fig. 4. Spatial variation of organic matter and $\varphi$ sampled at Ubatuba and Caraguatatuba regions located on the northern coast of São Paulo State, south-eastern Brazil. Mean \pm standard deviation are given for each region.

temperature, salinity and type of bottom are the main factors responsible for this fluctuation in tropical waters.

In accordance with Matsuura (1986) and Borzone et al. (1999), depths from the shore to the $50 \mathrm{~m}$ isobath are occupied by the $\mathrm{CW}$ in south and south-eastern Brazil, mainly during the summer. However, the presence of the CW occupying the coastal area during the autumn was registered by Pires-Vanin (2001) in São Sebastiaõ Channel, inner shelf of São Paulo. In the present study, the highest densities of $P$. brasiliensis occurred in waters where the temperature ranged from 22 to $24^{\circ} \mathrm{C}$. This temperature range along with low salinity indicates the presence of the CW. High temperature $\left(20-22^{\circ} \mathrm{C}\right)$ and low salinity $(34-35)$ was also observed by Léo \& Pires-Vanin (2006) in south-eastern Brazil, which indicated the presence of the $\mathrm{CW}$ in depths up to $40 \mathrm{~m}$ isobath. Low salinity water mass is highly influenced by runoff caused by rainfall in the inner shelf (from the shore to $50 \mathrm{~m}$ isobath) (Occhipinti, 1963; Metzler et al., 1997). Thus, the presence of the CW on the coast of Ubatuba and Caraguatatuba was more expressive during the summer, showing the highest temperature registered during the study period.

Several works on ichthyofauna and demersal fish captured as by-catch by shrimp trawl, in south and south-eastern Brazil, also indicated that banded croaker was captured more during the summer and autumn (Nonato et al., 1983; Coelho et al., 1993; Rossi-Wongtschowski et al., 2008). Cátalan et al. (2006) reported that the combined effect of reproductive period or ontogenetic migrations and recruitment episodes can explain the seasonal changes in the abundance of demersal fish populations in coastal areas. Costa (2010) registered that the smallest individuals along with high number of juveniles

Table 2. Results of the two-way analysis of variance of mean abundance by region, season and depth. Significant differences at the level of $0.05^{*}$ and $0.01^{* *}$.

\begin{tabular}{lllll}
\hline Variable & Effect & $\begin{array}{l}\text { Degrees of } \\
\text { freedom }\end{array}$ & $\boldsymbol{F}$ & $\boldsymbol{P}$ \\
\hline Density $\left(\mathrm{fish} / \mathrm{m}^{2}\right)$ & Region & 1 & 2.462 & 0.119 \\
& Season & 3 & 2.998 & $0.034^{*}$ \\
& Region $\times$ season & 3 & 0.257 & 0.856 \\
& Depth & 6 & 5.327 & $0.000^{* *}$ \\
& Region $\times$ depth & 6 & 0.344 & 0.912 \\
\hline
\end{tabular}

of banded croaker were captured as by-catch in Ubatuba and Caraguataba regions, mainly during the summer and autumn, whereas the adults predominated during the winter and spring. Thus, the temporal variation in the density of banded croaker in the study areas can be attributed to the population behaviour such as recruitment and reproductive patterns, since the life cycle of this species is adapted to shallow areas (Braga, 1990).

Previous studies carried out by Castro-Filho et al. (2008) on the northern coast of São Paulo, registered that the SACW intrusion reached depths up to $50 \mathrm{~m}$ during the summer and $25 \mathrm{~m}$ during the spring. The absence of individuals captured in depths more than $25 \mathrm{~m}$ during spring can be attributed to the intrusion of the SACW since lowest values of temperature (mean of $20^{\circ} \mathrm{C}$ ) associated with salinity around 36 were registered during this season. Our results corroborate those of Rossi-Wongtschowski \& Paes (1993), who while studying the spatial-temporal distribution of the demersal fish community on the coast of Ubatuba, observed that the population of $P$. brasiliensis moved to shallow water $(20 \mathrm{~m})$ during the intrusion of the cold water mass.

Influence of the SACW on the spatial-temporal distribution of fish, including the sciaenid species, was observed by Rocha et al. (2010) in shallow waters in Palmas Bay, Ubatuba. However, the multiple regression analysis indicated the temperature as a significant factor only for the Ubatuba region, probably due to the fact that this region is more exposed than Caraguatatuba which reflects in an intense action of water masses such as SACW.

Depth appears to be an important factor in the spatial distribution of banded croaker, as they are more abundant in depths that range from 15 to $25 \mathrm{~m}$. Souza et al. (2008) reported the influence of the depth on the abundance of $P$. brasiliensis in the inner shelves of Ubatuba, Caraguatatuba and São Sebastião. Coelho et al. (1986) while studying the bottom trawling fisheries of the shrimp Xiphopenaeus kroyeri on the coast of São Paulo, registered that the sciaenids accounted for $60 \%$ from all fish captured as by-catch in the isobaths of $25 \mathrm{~m}$. Our results also corroborate those of Vazzoler (1975) and Haimovici et al. (1996) who reported on abundance of this sciaenid species in $20 \mathrm{~m}$ depths on the coastline of southern Brazil.

The type of sediment is of fundamental importance to the demersal fish distribution. Sand, mud, clay, rock and coral exhibit a specific fish community and invertebrates that are 




Fig. 5. Variation in mean + standard deviation density of Paralonchurus brasiliensis captured as by-catch by season and mean depth. On the bar in parentheses, is indicated the total number of individuals captured.

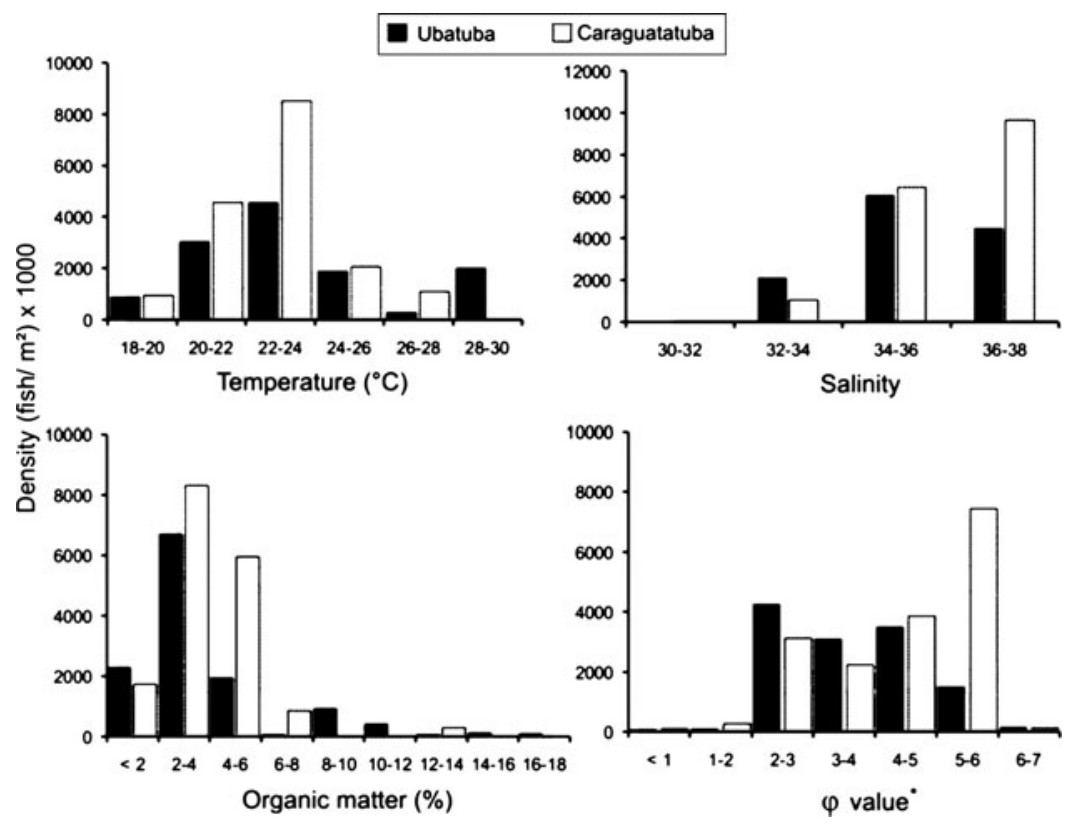

Fig. 6. Variation of the mean density of Paralonchurus brasiliensis collected in the regions Ubatuba and Caraguatatuba by classes of environmental factors. ${ }^{*}, \varphi$ values range: $-1=\varphi<0$ (very coarse sand); $0=\varphi<1$ (coarse sand); $1=\varphi<2$ (medium sand); $2=\varphi<3$ (fine sand); $3=\varphi<4$ (very fine sand); $\varphi \geq 4$ (silt clay).

important as food for demersal fish (Lowe-Macconnell, 1987). In general, banded croaker showed high density in depths where the sediment ranged from fine sand to silt-clay. Braga et al. (1985) reported that P. brasiliensis shows preference for prey that live above or that burrow in the sediment, mainly crustaceans and polychaetes. These benthic invertebrates are more abundant in fine sediment due to high concentration of detritus and nutrients (Furtado et al., 2008; Soares et al., 2008). Furthermore, the distribution of these benthic communities is affected by depth and the seasonal intrusion of water masses on the Brazilian south-eastern shelf (Pires, 1992; Pires-Vanin \& Santos 2004; Léo \& Pires-Vanin, 2006).

Muto et al. (2000) and Rossi-Wongtschowski et al. (2008) reported that depth and temperature were the main factors that influenced the spatial-temporal variations in the demersal fish community in the São Sebastião region. However, the environmental factors can influence the distribution of a unique species in different ways in different regions. Thus, the factors closely related to sediment can be more important in a sheltered area than an exposed one, which can explain the significant effect of the $\varphi$ and organic matter content on the variance of $P$. brasiliensis density in Caraguatatuba. In general, the variation of this fish population density can be attributed mainly to the presence of the water masses and the type of the sediment that is related to the location of the area and food availability.

Studies on the $P$. brasiliensis population on the coastal areas, mainly in shrimp fishery ground, are scarce despite the importance of this species for the ecosystem. However studies focusing on reproduction, growth, feeding and early development stages in relation to environmental factors and shrimp trawl fishery would help to understand better the population dynamics and its role in the ecosystem. 


\section{ACKNDWLEDGEMENTS}

The authors are grateful to FAPESP (Fundação de Amparo à pesquisa do Estado de São Paulo) for financial support, to the NEBECC for samplings, the CAPES/REUNI for a Postgraduate Scholarship, Dr Sathyabama Chellappa for the English review (UFRN) and two anonymous referees for valuable comments that helped us improve this paper.

\section{REFERENCES}

Araújo F.G., Azevedo M.C.C., Silva M.A, Pessanha A.L.M., Gomes I.D. and Cruz-Filho A.G. (2002) Environmental influences on the demersal fish assemblages in the Sepetiba Bay, Brazil. Estuaries 25, 441-450.

Borzone A.B., Pezzuto P.C. and Marone E. (1999) Oceanographic characteristics of a multi-specific fishing ground of the central south Brazil bight. Marine Ecology 20, 131-146.

Braga F.M.S., Braga M.A.A.S. and Goitein R. (1985) Fator de condição e alimentação Paralonchurus brasiliensis (Osteichthyes, Sciaenidae) na região da Ilha Anchieta (Lat. $23^{\circ} 33^{\prime} \mathrm{S}$-Long. $45^{\circ} 05^{\prime} \mathrm{W}$ ) Ubatuba, Estado de são Paulo. Naturalia 10, 1-11.

Braga F.M.S. (1990) Estudo da mortalidade de Paralonchurus brasiliensis (Teleostei, Sciaenidae), em área de pesca do camarão-sete-barbas (Xiphopenaeus kroyeri). Boletim do Instituto de Pesca 17, 27-35.

Castilho A.L., Furlan M., Costa R.C. and Fransozo V. (2008a) Abundance and temporal-spatial distribution of the rock shrimp Sycionia dorsalis Kingsley, 1878 (Decapoda, Penaeoidae) from the northern coast of São Paulo state, Brazil. Senckenbergiana Marítima $38,75-83$.

Castilho A.L., Pie M.R., Fransozo A., Pinheiro A.P. and Costa R.C. (2008b) The relationship between environmental variation and species abundance in shrimp community (Crustacea: Decapoda: Penaeoidea) in south-eastern Brazil. Journal of the Marine Biological Association of the United Kingdom 88, 119-123.

Castro-Filho B.M., Miranda L.B. and Myao S.Y. (1987) Hydrographic conditions on the continental shelf off Ubatuba: seasonal and meso-scale variability. Brazilian Journal of Oceanography 35, 135151. [On line.]

Castro-Filho B.M. and Miranda L.B. (1998) Physical oceanography of the western Atlantic continental shelf located between $4^{\circ} \mathrm{N}$ and $34^{\circ} \mathrm{S}$ coastal segment $(4, \mathrm{~W})$. In Robinson A.R. and Brink K.H. (eds) The sea. New York: John Wiley, pp. 209-251.

Castro-Filho B.M., Miranda L.B., Silva L.S., Fontes R.F.C., Pereira A.F. and Coelho A.L. (2008) Processos físicos: hidrografia, circulação e transporte. In Pires-Vanin A.M.S. (org.) Oceanografia de um Ecossistema Subtropical: Plataforma de São Sebastião, SP. São Paulo: Editora da Universidade de São Paulo, pp. 59-121.

Catalán I.A., Jiménez M.T., Alconchel J.I., Prieto L. and Muñoz J.L. (2006) Spatial and temporal changes of coastal demersal assemblages in the Gulf of Cadiz (SW Spain) in relation to environmental conditions. Deep-Sea Research II 53, 1402-1419.

Chao L.N. (1986) A synopsis on zoogeography of the Sciaenidae. In Uyeno T., Arai R., Taniuchi T. and Matsuura K. (eds) Indo-Pacific fish biology: proceedings of the Second International Conference on Indo-Pacific Fishes. Tokyo: Ichthyological Society of Japan, pp. 570589 .

Coelho J.A.P., Puzzi A., Graça-Lopes R., Rodrigues E.S. and Prieto Jr O. (1986) Análise da rejeição de peixes na pesca artesanal dirigida ao camarão sete-barbas (Xiphopenaeus kroyeri) no litoral do estado de São Paulo, Brasil. Naturalia 13, 51-61.
Coelho J.A.P., Graça-Lopes R.G., Rodrigues E.S., Puzzi A. and Farias D.S. (1993) Aspectos biológicos e pesqueiros do Sciaenidae Paralonchurus brasiliensis (Steindachner, 1875) presente no rejeitado da pesca artesanal dirigida ao camarão sete-barbas (São PauloBrasil). Boletim do Instituto de Pesca 20, 95-101.

Cohen J., Cohen P., West S.G. and Aiken L.S. (2003) Applied multiple regression/correlation analysis for the behavioral sciences. 3 rd edition. Hillsdale, NJ: Lawrence Erlbaum Associates.

Costa E.F.C. (2010) Influência dos fatores abióticos sobre a variação espaço-temporal de Paralonchurus brasiliensis (Steindachner, 1875) (Pisces, Sciaenidae) componente da fauna acompanhante da pesca de camarões no Litoral Norte de São Paulo. Masters dissertation. Universidade Federal do Rio Grande do Norte, Natal, Brazil.

Dias J.F. and Katsuragawa M. (2009) Mortalidade desnecessária. In Oceanos: origens, transformações e o futuro, 2: geopolítica, pesca e riquezas marinhas. São Paulo: Duetto, Scientific América Brasil, pp. $56-61$.

Folk R.L. and Ward W.C. (1957) Brazos River bar (Texas): a study in the significance of the grain size parameters. Journal of Sedimentary Petrology 27, 3-57.

Furtado V.V., Barcellos R.L., Conti L.A. Rodrigues M. and Mahiques M.M. (2008) Sedimentação. In Pires-Vanin A.M.S. (org.) Oceanografia de um ecossistema subtropical: plataforma de São Sebastião, SP. São Paulo: Editora da Universidade de São Paulo, pp. $141-180$.

Golden Software (2002) Surfer, version 8. Golden, CO: Golden Software Inc.

Gotelli N.J. and Ellison A.M. (2004) A primer of ecological statistics. Sunderland, MA: Sinauer Associates Inc.

Haimovici M., Martins A.S. and Vieira P.C. (1996) Distribuição e abundância de peixes teleósteos demersais sobre a plataforma continental do sul do Brasil. Revista Brasileira de Biologia 56, 27-50.

Jennings S., Kaiser M.J. and Reynolds J.D. (2000) Marine fisheries ecology. Oxford: Blackwell Science.

Katsanevakis S., Maravelias C.D., Damalas D., Karageorgis A.P., Tsitsika E.V., Anagnostou C. and Papaconstantinou C. (2009) Spatiotemporal distribution and habitat use of commercial demersal species in the eastern Mediterranean Sea. Fisheries Oceanography 18, 439-457.

Koranteng K.A. (2001) Structure and dynamics of demersal assemblages on the continental shelf and upper slope off Ghana, West Africa. Marine Ecology Progress Series 220, 1-12.

Léo F.C. and Pires-Vanin A.M.S. (2006) Benthic community under the influence of the South Atlantic Coastal Water intrusion onto Brazilian SE shelf: a comparison between an upwelling and a nonupwelling ecosystem. Journal of Marine Systems 6o, 268-284.

Lowe-Mcconnell R.H. (1977) Ecology of fishes in tropical waters. London: The Camelot Press.

Lowe-Mcconnell R.H. (1987) Ecological studies in tropical fish communities (Cambridge Tropical Biology Series). Cambridge: Cambridge University Press.

Mantelatto F.M.L. and Fransozo A. (1999) Characterization of the physical and chemical parameters of Ubatuba Bay, northern coast of São Paulo state, Brazil. Revista Brasileira de Biologia 59, 23-31.

Matsuura Y. (1986) Contribuição ao estudo da estrutura oceanográfica da região sudeste entre Cabo Frio (RJ) e cabo de Santa Marta Grande (SC). Ciência e Cultura 38, 1439-1450.

Menezes N.A. and Figueiredo J.L. (1980) Manual dos peixes marinhos do Sudeste do Brasil, Volume IV. Teleostei (3). São Paulo: Museu de Zoologia da Universidade de São Paulo. 
Metzler P.M., Glibert P.M., Gaeta S.A. and Ludlan J.M. (1997) New and regenerated production in the South Atlantic off Brazil. Deep-Sea Research I 44, 636-384.

Muto E.Y., Soares L.H. and Rossi-Wongtschowski C.L.D.B. (2000) Demersal fish assemblages off São Sebastião, southeastern Brazil structure and environmental conditioning factors (summer 1994). Revista Brasileira de Oceanografia 48, 9-27.

Nelson J.S. (2006) Fishes of the world. 4 th edition. New York: John Wiley and Sons Inc.

Nonato E.F., Amaral A.C.Z. and Figueiredo J.L. (1983) Contribuição ao conhecimento da fauna de peixes do litoral norte do Estado de São Paulo. Boletim do Instituto Oceanográfico 32, 143-152.

Occhipinti A.G. (1963) Climatologia do litoral sul brasileiro. Contribuições Avulsas do Instituto Oceanográfico 3, 1-86.

Pires A.M.S. (1992) Structure and dynamics of benthic megafauna on the continental shelf offshore of Ubatuba, south-eastern Brazil. Marine Ecology Progress Series 86, 63-76.

Pires-Vanin A.M.S. and Matsuura Y. (1993) Estrutura e função do ecossistema de plataforma continental da região de Ubatuba, estado de São Paulo: uma introdução. Publicação Especial do Instituto Oceanográfico $10,1-8$.

Pires-Vanin A.M.S., Rossi-Wongtschowski C.L.D.B., Aidar E., Mesquita H.S.L., Soares L.S.H., Katsuragawa M. and Matsuura Y. (1993) Estrutura e função do ecossistema de plataforma continental do Atlântico Sul brasileiro: síntese dos resultados. Publicação Especial do Instituto Oceanográfico 10, 217-231.

Pires-Vanin A.M.S. (2001) Identifying the components of ecological variation in a marine benthic megafauna. Revista Brasileira de Oceanografia 49, 29-38.

Pires-Vanin A.M.S. and Santos M.F.L. (2004) Structure and dynamics of the macrobenthic communities of Ubatuba Bay, south-eastern Brazilian coast. Brazilian Journal of Oceanography 52, 59-73.

Rocha G.R.A. and Rossi-Wongtschowski C.L.D.B. (1998) Demersal fish community on the inner shelf of Ubatuba, south-eastern Brazil Revista Brasileira de Oceanografia 46, 93-109.

Rocha M.L.C.F., Fernandez W.S. and Paiva-Filho A.M. (2010) Spatial and temporal distribution of fish in Palmas Bay, Ubatuba, Brazil Brazilian Journal of Oceanography 58, 31-43.
Rossi-Wongtschowski C.L.D.B. and Paes E.T. (1993) Padrões espaciais e temporais da comunidade de peixes demersais do litoral norte de São Paulo-Ubatuba, Brasil. Publicação Especial do Instituto Oceanográfico $10,169-188$.

Rossi-Wongtschowski C.L.D.B., Soares L.S.H. and Muto E.Y. (2008) Ictiofauna. In Pires-Vanin A.M.S. (org.) Oceanografia de um ecossistema subtropical: plataforma de São Sebastião, SP. São Paulo: Editora da Universidade de São Paulo, pp. 381-403.

Soares L.S.H. and Vazzoler A.E.A. de M. (2001) Diel changes in food and feeding activity of Sciaenid fishes from the South-eastern Atlantic, Brazil. Revista Brasileira de Biologia 61, 197-216.

Soares L.S.H., Muto E.Y., Gasparro M.R. and Rossi-Wongtschowski C.L.D.B. (2008) Organização trófica de peixes. In Pires-Vanin (org.) Oceanografia de um ecossistema subtropical: plataforma de São Sebastião. São Paulo: Editora da Universidade de São Paulo, pp. 405-425.

Souza U.P., Costa R.C., Martins I.A. and Fransozo A. (2008) Associação entre as biomassas de Sciaenidae (Teleostei: Perciformes) e de camarões Penaeoidae (Decapoda: Dendrobranchiata) no litoral norte do estado de São Paulo. Biota Neotropica 8, 21-30.

Tucker M. (1988) Techniques in sedimentology. Oxford, London, Edinburgh, Boston, Palo Alto and Melbourne: Blackwell Scientific Publications.

Vazzoler G. (1975) Distribuição da fauna de peixes demersais e ecologia dos sciaenidae da plataforma continental brasileira, entre as latitudes $29^{\circ} 21^{\prime} \mathrm{S}$ (Torres) e $33^{\circ} 41^{\prime}$ (Chuí). Boletim do Instituo Oceanográfico $24,85-169$.

Wentworth C.K. (1922) A scale of grade and class terms for clastic sediments. Journal of Geology 30, 377-392.

and

Zar J.H. (1999) Biostatistical analysis. Upper Saddle River, NJ: Prentice-Hall.

Correspondence should be addressed to:

E.F.S. Costa

Postgraduate Programme in Biological Oceanography Institute of Oceanography, Universidade de São Paulo Praça do Oceanográfico 191, SP, Brazil, Zip code: 05508-120 email: eudriano@usp.br 